attended, among others, by Prof. P. M. S. Blackett, London; Prof. E. B. Chain, Rome; Prof. Louis Fieser, Harvard University; Prof. H. A. Krebs, Oxford ; Sir Ben Lockspeiser ; Prof. David Rittenberg, New York ; and Sir Robert Robinson, London. Prof. Saul Adler, of the Hebrew University at Jerusalem, and Prof. S. G. Zondek, of Tel Aviv, attended in their capacities as members of the Institute's Board of Governors.
In addition to the resolution extending postgraduate teaching, the Board of Governors dealt with and decided upon certain administrative reorganization and the consolidation of the financing policy.

When eventually put into effect, the postgraduate teaching curriculum will be of great advantage to Israel, which has still to develop and broaden this aspect of its higher learning.

\title{
OBITUARIES
}

\section{Sir Henry Guy, C.B.E., F.R.S.}

Britais has always been rich in engineers whose interests lay in the field of practical construction. It has never been quite so prolific in engineers concerned with engineering science. Although in recent years ill-health put a severe restriction on his activities, the death on July 20 of Sir Henry Guy has removed one from the smaller band of those who took an active and prominent part in the encouragement and organization of engineering research.

His interest was no theoretical interest. It was founded on a wide practical experience as an engineering designer. For more than twenty years he occupied the responsible position of chief mechanical engineer to the Metropolitan-Vickers Electrical Co., Ltd., where, in the quest for ever-increasing thermal efficiency, he designed steam turbines which were not only notable advances in regard to the steam pressures and superheat temperatures that were used, but also in regard to the size of the units. The $100,000-\mathrm{kW}$. turbo-generator which is now accepted as the standard unit for large power stations had already been designed by Sir Henry Guy and constructed by his Company during the 1930's. When the Soviet Government invited competitive designs for a turbo-generator unit to be used as a basis for the development of power stations in the U.S.S.R., it was his design put forward by Metropolitan-Vickers that won the award and the contracts against world-wide competition.

No one was better able to assess the gaps in our knowledge of engineering science than Sir Harry, as his opinion was fortified by his recollection of those many occasions when faith in his own intuition had to replace the experimental knowledge that was wanting.

When the Advisory Council of the Department of Scientific and Industrial Research, of which Sir Henry Guy was a member at the time, considered during the last year of the Second World War how the pattern of research should be developed in Britain, the need for more research on engineering subjects was specially emphasized. A committee under Sir Henry's chairmanship was set up to consider what practical action should be taken, and it was the recommendation of the Guy Committee that led to the foundation of the Mechanical Engineering Research Laboratory now sited at East Kilbride.

No one better could have been chosen as chairman for this purpose. His wide and detailed knowledge of engineering in its many branches made him visualize the sections into which research on fundamental science could be divided without multiplicity, and his guidance was invaluable. The creation of the Mechanical Engineering Research Laboratory became one of his principal interests in later years, and the fact that the pattern of its organization has not been changed since it started has confirmed the wisdom of his views and outlook.

Sir Henry Guy was naturally chosen as the first chairman of the Mechanical Engineering Research Board, and his kindly and tolerant manner in the chair and the sincerity of his desire to convert those who differed from him, or to be himself converted, helped the new organization to surmount successfully its teething troubles. Even during the period when his health was causing anxiety, nothing gave him greater pleasure than to hear from time to time of its success.

He served as secretary of the Institution of Mech. anical Engineers during the period 1942-51.

A. MoCANCE

\section{Mr. C. F. Charter, O.B.E.}

Cecil Fremerick Charter died in London after a brief illness on January 27. He was then director of Soil and Land-Use Survey in the Gold Coast. That country has lost a good friend, a good organizer and an outstanding scientist.

Charter was educated at the Lowestoft Secondary School and at Trinity Hall, Cambridge. After teaching at the Tientsin Grammar School in North China and at the Antigua Grammar School, Charter accepted an invitation to undertake a study of the soils of Antigua and Barbuda. Charter's report on the soil survey of Antigua and Barbuda published in 1937 was reprinted in 1947 ; in collaboration with P. E. Turner he published in 1939 observations on soils of sugar estates in Trinidad. During 1933-44 he was local scientific officer of the Antigua Sugar Cane Investigation Committee. In 1940 he visited British Honduras and wrote an illuminating report on the soils, many of which are impoverished by long exposure to heavy rain. Charter described as a maturity sequence the soils formed on non-calcareous alluvium of various ages. The alluvium covers a wide area and carries swamp forest, well-drained broad-leaf forest, conifers or poor savannah. of these, the last two indicate moderate or severe impoverishment accompanied by development of a heavy, feebly permeable, brightly mottled subsoil.

In 1944 Charter was appointed soil chemist in the Gold Coast Department of Agriculture and worked in the West African Cocoa Research Institute. In 1949 he was promoted chief soil scientist of the Soil Survey Division, Department of Agriculture. In 1951 he was made director of a newly created Department of Soil and Land-Use Survey and was made O.B.E. He paid brief visits to the Belgian Congo, South Africa, Tanganyika and British Guiana in 
1948-50, and in 1955 made an extensive study tour of the United States of America under the auspices of the Foreign Operations Administration.

In the Gold Coast, Charter developed a new tech. nique in soil survey, employing methods adapted from those used in ecological surveys. Soil, vegetation and land-use were sampled or recorded, at regular intervals along traverse lines and at regular intervals across the grain of the topography. Soils were mapped by topographical associations, but within each of the latter, sample strips a mile long by a quarter mile broad were mapped in complete detail to illustrate the soil, vegetation and land-use patterns occurring. Such work involved the use of large numbers of semi-skilled local assistants, the majority of whom Charter had to train himself.

One important detail of the procedure evolved by Charter was the orderly preservation of samples of soil and rock and the regular comparison of each day's findings with the selected standard samples. $\mathrm{He}$ was fortunate in that all his African junior assistants could read and write English; their work, however, was closely checked by those with better education or longer experience. The work was done with accuracy and enthusiasm and was generously supported by the Gold Coast Government, which constructed at Kumasi excellent laboratories and offices for Charter's department. At the time of his death, the department had an establishnient of some twenty professional staff and 150 junior technical assistants of varying grades.

At the Cocoa Conference of 1949 Charter described the principal cocoa soils of the Gold Coast and riscussed the phenomenon of soil creep occurring there and in Central America and the West Indies. After a visit to Tanganyika in 1950 , he came to realize that many tropical soils were not truly sedentary but had developed in 'drift' parent materials. In a paper submitted to the Conference of the Consultative Committee for Tropical Africa on the mechanization of agriculture (Entebbe, 1955), Charter advocated bush fallows for maintenance of fertility in peasant agriculture. In an important paper presented at the Cocoa Conference of 1955 he noted that in the Gold Coast cocoa had failed to survive on acid soils ('oxysols') deficient in divalent bases, but had survived on the less acid and more fertile 'ochrosols'. He stressed the importance of including magnesium in fertilizer trials with cocoa. Charter associated the 'oxysols' with the reddish-yellow latosols of Kellogg and Davol (1949). He noted that the relatively infertile 'oxysols' are formed, where annual rainfalls exceed 70-80 in., from the weathering products of highly siliceous rock (quartzites) or from those of pyritiferous sediments which set free sulphuric acid during decomposition. In fact, appreciable amounts of sulphate in the subsoil of Gold Coast 'oxysols' had been found by the analyses of Charter's colleague, A. S. de Endredy (unpublished observation). A brief statement of Charter's views on the broader aspects of soil classification is given in the Proceedings of the Fifth International Congress of Soil Science $(4,497-$ 499). A further account of Charter's views has been prepared for the Sixth International Congress of Soil Science by his colleague, H. Brammer.

Charter was born on December 4, 1905. A son and daughter, children of his first marriage, survive him. Herbert Greene

\section{NEWS and VIEWS}

\section{Metallurgy at Leeds :}

Prof. N. J. Petch

THE Department of Coal, Gas, and Fuel Industries with Metallurgy in the University of Leeds is to be re-organized into the three Departments of Fuel, of Chemical Engineering and of Metallurgy. Collectively they will form the Houldsworth School of Applied Science. Dr. N. J. Petch, at present reader in metallurgy, has been appointed to the new chair of metallurgy created during this re-organization.

After taking a degree in chemistry at Queen Mary College, London, in 1936, Dr. Petch spent a year studying engineering and then read metallurgy at the University of Sheffield, where he took his B.Met. in 1939 and was awarded the Mappin Medal. This varied training was completed by three years as a research assistant in the Crystallographic Department at the Cavendish Laboratory. His researches during this period culminated in papers on the positions of the carbon atoms in cementite, austenite and martensite. Dr. Petch then went to the Royal Aircraft Establishment, where he organized a new section of the Metallurgy Department, dealing with X-ray diffraction problems and routine radiography. H.e also began to take an interest in the field of fracture in metals, with which his name is now particularly associated. Initially this interest was stimulated by investigations of the mechanism of the hydrogen embrittlement of steels; but during the period 1946-49 which Dr. Petch spent in the Cavendish Laboratory with the team led by Dr. E. Orowan, his interests widened to include many fundamental aspects of fracture. Since 1949, when he was appointed reader in metallurgy in the University of Leeds, Dr. Petch has continued his studies of fracture and has published many important papers in the field. A problem common to all university departments teaching the applied sciences is to maintain an adequate balance in lectures between the rapidly expanding new lnowledge and the established classical material. Dr. Petch, who is responsible for the teaching courses in metallurgy, has, during the tenure of the readership, carried out a careful roorganization to maintain the balance.

\section{Geography at Liverpool :}

Prof. R. W. Steel

Mr. R. W. SteEL has been appointed John Rankine professor of geography in the University of Liverpool as from January of next year, a post which has been vacant since the death in 1955 of Prof. W. Smith. Mr. Steel has spent his academic life in Oxford. He was an open exhibitioner of Jesus College, Oxford, and while still an undergraduate won the Royal Geographical Society's Essay Prize in 1936. In 1938, he was Draper's Research Scholar and carried out some research work in Sierra Leone. He made a second expedition to West Africa, jointly with an economist and an anthropologist, during 1945-46, and has recently returned from a further visit to Central Africa and East Africa. He has for many years been lecturer in Colonial geography in the 